\title{
Black Gold: The Best alternative in Waste Management via Agriculture
}

\author{
El-Jawaher A. Bin Dohaish* \\ Department of Biology, University of Jeddah, Saudi Arabia
}

Submission: April 01, 2019; Published: April 15, 2019

"Corresponding author: El-Jawaher A. Bin Dohaish, Faculty of Science, Department of Biology, University of Jeddah, Saudi Arabia

\begin{abstract}
Vermicomposting is a modern technique in agriculture to transform different kinds of organic waste into utilizable products that contain different plant nutrients. Special types of worms are being used in Vermicomposting and in this review, we discuss the scientific results of different kinds of composting and the best choice in agriculture to get rid of waste and cultivation with vermi-worms (earthworms). In Addition, we discuss the previous studies in vermicomposting that proves it is a unique addition and a sustainable method to control waste and manage it. Keywords: Vermicompost; Organic compost; Vermi-worm; Eisenia fetida; Red wiggler; Nutrients; Waste management; Agriculture Abbreviations: SWM; Solid Waste Management; MSW: Municipal Solid Waste
\end{abstract}

\section{Introduction}

The constant increase in population, urbanization and economic growth have led to a massive increase in solid wastes and pollutants [1]. When these contaminants aren't disposed or managed in a safe way, they cause major threats to the ecosystem in air, water, land and living organisms, which can cause serious and critical health hazards. The amount of municipal solid waste disposed of in the environment worldwide is estimated between 1.3 and 1.9 billion tons per year and is expected to rise to approximately 2.2 billion tons per year by 2025 , which is considered to be a hazardous crisis and a matter of high concern [2].

Solid Waste Management (SWM) is characterized as a discipline associated with the collection, control, storage, transfer, process, and disposal of Municipal Solid Waste (MSW) in a civilized manner that best serves the environment, the public health and the economy [3]. Globally, an outstanding amount of money goes towards waste management. Asian countries alone have spent around 25 billion American dollars on solid waste management per year in the early 1990 s and the figure is expected to rise in 2025 to reach 50 billion American dollars [4].

Besides the increasing need of controlling waste, there has been a request for agrochemical free crops and vegetables. Since the 1960's the green evolution relied mostly on agrochemicals, it enhanced the productivity of the crops but also severally harmed the environment and society as the health of agriculture is directly related to the public health [5]. It destroyed the beneficial organisms in the soils and impaired their natural fertility and pest resistance.

In the last few decades, various techniques have been introduced in association with waste management to save our environment from life-threatening pollutants as it is an essential public request and highly important to preserve our environment. One of those techniques known in agriculture is known as vermicompositing where it is an economical alternative, socially safe and sustainable.

Traditionally, worms have been used as fishing bait and a protein source for many animals. Several studies on different animals, birds, and fish have shown excellent results when feeding animals with a worm [6] and view earthworms as being a natural source of food for birds and other animals in the wild. Recently, vermi-worms have proven their ability in transforming waste into a utilizable product as well as their ability to be used as an excellent tool in improving the health of the agriculture due to them working as cleansers that are capable of biologically and safely degrading wastes [7].

\section{Composting}

Composting is a natural biological process that leads to the biodegradation of organic wastes to a stable end product known as compost which can be used for different agricultural needs. Therefore, interest in compost is considered a component of waste management as it limits the pollution caused by overusing other forms of chemical composts [8]. Composting works on degrading 
all organic materials that are biodegradable as well as degrading the polluting matter that can cause unpleasant odors which in return would impact the ecosystem [9]. There are various types of composting, a few of them being; a) Anaerobic composting and b) Aerobic composting c) vermicomposting.

a. Anaerobic composting is the degradation of organic matter in the absence of air where the anaerobic organisms produce intermediate compounds such as methane, organic acids and other substances such as hydrogen sulphide [10]. Anaerobic composting is a low-temperature process. In Addition, the compost isn't transformed completely and can contain lumped mass and compounds that are toxic to the plant.

b. Aerobic composting is the degradation of organic matter in the presence of air where the microorganisms degrade the organic matter producing carbon-dioxide, ammonia, water, heat and humus [11] and forms an organic stable product. Humus is a fully decomposed compose and is made up of remnants of leaves and grass and other organic matters [12]. Other intermediate products are formed that are made of organic acids, although the compost produced is of low toxicity on the plant. The heat produced from the microorganisms and bacteria's activities fastens the process of breaking down the proteins, fats and complicated carbohydrates in the plant. Thus, "Hot composting" takes less time and therefore aerobic composting is considered more effective than anaerobic composting.

c. Vermicomposting is a simple process of composting where certain species of earthworms (such as Eisenia feotida and African Night Crawler) are used to enhance the process of waste conversion and produce a better product. Vermicompost is used extensively due to its low price point and high efficiency [13]. It is a porous process where microorganisms and earthworms are used that are active at 10-32 ${ }^{\circ} \mathrm{C}$ (not temperature around but temperature within the pile of moist organic material) and the earthworms feed on organic waste and pass it through their digestive system where it comes out in the form of compost known as Vermicompost. This compost enhances the growth of plants, reduces plant diseases, increases porosity and microbial activity in the soil, enhances water retention capacity and aeration within the soil $[14,15]$. Vermicomposting is called the "cold" composting due to the low range of heat created during the process; and if the temperature increased within the pile, the worms wouldn't continue in the vermicomposting operation [7].

\section{Vermiworm}

Although there are over 3000 types of worms around the world, only 384 types are suitable for agriculture such as Eisenia fetida, Lumbricus rubellis [16,17], Eisenia Andrei, Perionyx excavatus, Eudrilus eugeniae, Enchytraeids, Dendrobaena veneta, and Perionyx hawayana. Eisenia fetida and Lumbricus rubellis are the most often used species due to their high efficiency and easy maintenance [18]. They are vastly used in Vermicomposting as well as in the form of fish bait and can be found in organic materials such as compost or litter manures or near fresh water and even in snowy patches [9].

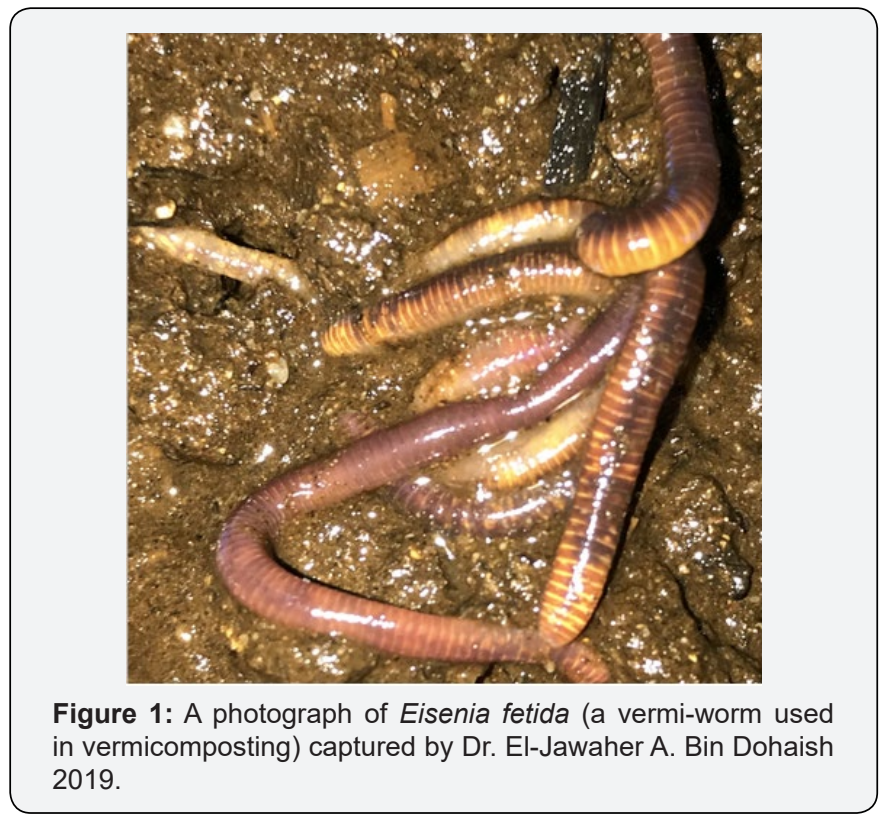

The classification of Eisenia fetida falls under Epigeic species and has many different names such as manure worms, tiger worms, red wigglers, and red worms. Eisenia fetida is shortly known as " $E$. fetida" and has proven to be highly effective in converting waste of many forms such as wastewater $[19,20]$ into materials that can be benefited from. This species grows effectively in a room temperature environment and normally feeds on organic materials and wastes and converts them into utilizable materials rather than their accumulation in the environment and food web [21]. Eisenia fetida was previously known as Eisenia foetida and lives in the European continent and recently all around the world except for Antartica due to its environmental condition. Eisenia fetida is a red worm with a yellowish orange tail (Figure 1). Earthworms are cylindrical in shape and have a segmented body that tapers off at both ends. Worms have a brain and 5 hearts and a digestive system that is responsible for the composting process. Earthworms are photophobic, which means they're highly sensitive to light. They have the ability to process large amounts (almost its body weight) of organic matters in ideal conditions. Eisenia fetida has an effective defense mechanism where it can deplete a yellow liquid with an unpleasant odor that makes possible predators flee away from it [23].

Worms are hermaphrodites, which means they are both male and female. However, each worm still needs another worm of its species to mate, where each worm fertilizes the other eggs. The fertilized eggs contain a mucous tube that slips over its head and then into the soil through its mouth as an egg-case or commonly known as a cocoon. Cocoons are small spherical balls that contain various worms inside it. They are about the size of a match stick's head and change colors as the juvenile worms develop. It starts out as pale yellow and before hatching, when the hatchlings are ready 
to emerge, the cocoons are reddish-brown. They reproduce every 7 to 10 days if they are kept in the recommended environment with other worms for mating. The difference between the juveniles and adult worms is their color being slightly lighter. It takes around 60-90 days for the worm to mature and would weigh about $0.55 \mathrm{~g}$ [22] and can reach $3-10 \mathrm{~cm}$ in length. The initial worms can remain healthy and in sustainable amounts if it is reared in a safe way [7] There are various places in which vermiworms can be obtained.

Vermiworms are termed on the certain types of earthworms that act as biological agents to consume those wastes and to deposit excreta in the process called vermicompost. Vermiculture is termed on the sustainable preservation of the number of worms to receive a sustainable product [24]. Vermicomposting is a term of the process by which all types of biodegradable wastes such as farm wastes, kitchen wastes, market wastes, biowastes of agro-based industries, livestock wastes etc are converted while passing through the worm gut to nutrient rich vermicompost. Vermicompost is termed on the excreta of earthworm that is capable of improving soil health and nutritional status.

\section{Effective Factors on vermicomposting:}

a. The organic matter used in vermicomposting isn't considered the main factor in the process, there are other factors that can easily effect vermicomposting such as: Carbon to nitrogen ratio in the compost $(\mathrm{C} / \mathrm{N})$ is a significant factor. The fungi and bacteria in vermicompost will digest or oxidize carbon as an energy source and ingest nitrogen for protein synthesis, therefore, carbon can be considered as the nutrimental source and nitrogen is the digestive enzyme, which is why the organic matter placed in the pile should have enough "food: enzyme" ratio, aka, "Carbon: Nitrogen" ratio. The estimated measurement is 30 parts carbon to 1 part nitrogen (30:1), which should be enough or sufficient for the rapid composting process. However, the presence of too much nitrogen may create ammonia gas which will create an unpleasant smell and affect the composting process or even kill the worms [25].

b. Moisture inside the pile is one of the make or break factors in vermicomposting. The microorganisms in the pile can only use organic molecules that are dissolved in water. Therefore, the pile must contain a moisture content of $50-80 \%$. When the moisture level drops, the microbial activity will slow down and if it increases above $80 \%$ it will hinder the aeration needed [24]. The change in moisture level (such as the manure being too soaked or too dry) can significantly affect the safety of the worms and can even lead to their death [24].

c. Aeration or the amount of oxygen present in the pile should be carefully maintained as the decomposition takes up all the available oxygen. Aeration means to provide a passageway for oxygen in the middle of the pile where it is needed. Efficient and successful decomposing can only occur with the right amount of oxygen available for the worms. Aeration can be done with a special tool called "Aerator" [22]. A high rate of aeration, however, would decrease the moisture level of the pile and increase the temperature which would kill the worms [26].

d. Due to the microorganisms generating heat in the process of decomposing, the pile can easily get overheated which can be lethal to the worms. Thus, the temperature should be around $15-32{ }^{\circ} \mathrm{C}\left(59-77^{\circ} \mathrm{F}\right)$, where the worms feed most rapidly. Vermi worms can live in temperature as cold as $10^{\circ} \mathrm{C}$ although the process would slow down while temperatures above $30{ }^{\circ} \mathrm{C}$ would harm or even kill the worms [22].

e. One of the steps that would speed up the composting process is increasing the surface area of the material to be composted. It is an essential factor to make it easier for microorganisms to ingest the waste material. This technique can be done by shredding or cutting up the material into small pieces as the increase in surface area means that the microorganisms will be able to digest more material where the earthworms and bacteria will also break down the matter into smaller pieces. Materials such as bread tend to mold and cause an unpleasant smell as well as reduce the oxygen level in the pile so it is best to use food such as melons or cantaloupes [27].

f. The $\mathrm{pH}$ level in the compost pile depends on the decomposition rate by the worm and the type of feed material. Organic acids may be released during the process which causes a decrease in the $\mathrm{pH}$. The production of ammonia gas from the increase of nitrogen level can raise the $\mathrm{pH}$ level. Therefore, a $\mathrm{pH}$ level of 6.5 to 8.5 is suitable for the compost's microorganisms [22].

g. The bedding of the vermiworm is its shelter, it needs to be comfortable and ready for the worm to keep them healthy and safe. The bedding provides a balanced diet (waste), a moisture filled environment, and an aerated home for the worms. It is essential to keep the bottom of the bin covered by bedding for a depth of at least 4-6 inches. Mixing materials for bedding would ensure you a more successful process (such as cow dung or soil Figure 2). Providing shredding newspaper, or using straw, or coconut fibers (Coir) or shredded leaves mixed with soil will provide a good source of nutrients for your worms. It is important to use material that wouldn't compact the bedding to avoid the earthworm's death [7].

Setting-up a bed and harvesting: There are different types of Vermicomposting settings that depends on the intention of use, materials used, and quantity of the worms and the location of the composting system. A vermicompost's bed or "pile" is the shelter in which the vermi-worms would live, feed, reproduce and make the end product. Thus, the bedding is a very necessary part of the system that would determine the success or failure of the process.

Small scale vermicomposting systems: Small scale is often called bins or windrows and their size depends on the amount of waste that is going to be composted and the number of worms. A small Vermicomposting bin can vary in structure material (like wood or plastic) but should contain 1 pound of food for 1 pound of 
worms. The overloading of food would create a reaction (rotting of the food) that would generate heat and potentially kill the worms.

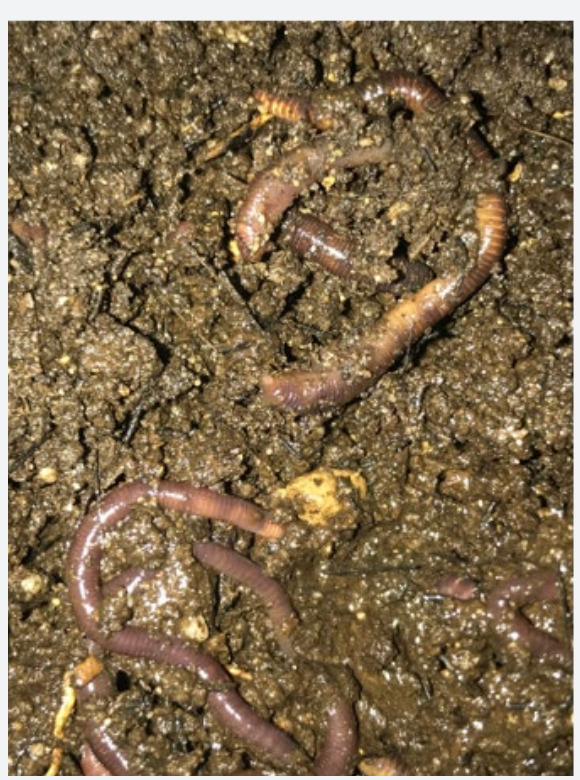

Figure 2: A photograph of Eisenia fetida (a vermi-worm used in vermicomposting) in soil captured by Dr. El-Jawaher A. Bin Dohaish

Large scale vermicomposting system: Is used when the quantity of worms and waste is usually enormous and requires more space. They are usually kept outdoors or in fields.

Precautions for small and large scale vermicomposting: Bins can be kept a) indoor or b) outdoors but certain measures need to be considered in each case.

a. If the bin is well maintained it is going to be odorless and thus can be kept indoors without any discomfort to the farmer or breeder. It can be kept under the kitchen sink or in a place away from light and possible predators while maintaining the same effective factors.

b. Outdoor bins can be more suitable if there is more than one bin or the space inside the house is insufficient. However, special measures should be taken during outdoors vermicomposting. The bin should be maintained in a temperature that is suitable for the worms production at all times. The bins should be protected from rain and wind and any possible aggressors such as rodents or other animals.

Setting up a vermicompost station requires certain steps as illustrated by Ramnarain et al. [28] where he followed the famous vermitechnique pattern by Ismail [29]:

a. A vermicompost station can be built in a shaded area with measurements of $10 \times 8 \times 3 \mathrm{~m} 3$.

b. The vermi-worms is to be cultured in a concrete unit of $150 \times 100 \times 60 \mathrm{~cm} 3$ with drainage holes (of $2 \times 2 \mathrm{~cm}^{2}$ ) to maintain the right moisture level by draining the excess water. c. The roof of the unit shall be made up of zinc sheets and the bottom should be isolated with paper while the walls of the unit would be built with wire mesh for a cooling effect and stable aeration

d. The first layer of the compost bed can be covered with broken bricks with $6-7.5 \mathrm{~cm}$ thickness with sand mixed within (or it can be substituted by sawdust or shredded dry paper mixed with soil [7]). This step is essential to maintain the drainage of water that would otherwise harm the vermi-worms.

e. The feeding material would be added days before the worms for the "initial composition" to take place.

f. The Eisenia foetida would be added to moistened soil as a layer of $15 \mathrm{~cm}$ into the unit.

g. Feeding material in Ramnarain et al. [28] study was cattle dung as the aim of the study was to test cow manure's effect on vermicompost. Some studies have used agricultural wastes [30] or domestic wastes when the system is built to recycle wastes at home.

h. The 4th layer shall consist of dry grass clippings (and rice straw) where Ramnarain et al. [28] obtained it from the University of Guyana's Garden in Georgetown, Guyana with the thickness of $10 \mathrm{~cm}$.

i. The unit shall be covered with layers of banana leaves (or a jute bag as recommended by S Karmakar et al. [31]) to protect the worms from direct sunlight and sprayed with water twice a week to maintain the recommended moisture level.

j. The temperature, $\mathrm{pH}$, moisture, and carbon: nitrogen ratio should be maintained throughout the process.

Harvesting the vermicompost is considered the final step in the process. The end product is usually black or dark brown crumbly soil. To maintain the worm's health and sustainability of the process, it is necessary to harvest the compost and change the bedding at least twice a year. The product can be harvested through placing the compost on a plastic sheet and shining a light on it or using direct sunlight, and as vermi-worms are photophobic, they would crawl away and the remaining compost can be brushed gently by hand on the outside [13]. The crawling worms can then be recollected for reuse. Some researches and farmers use a sieve to collect the vermicompost and separate it away from the worms. Although this method is effective, it has been reported that it can be traumatic for the worms and cocoons can be lost along the process [32].

\section{Feeding Types}

Every type of worm depends on the type of waste available, its quality and quantity and the type of composting system a breeder wishes to set up. Worms will eat almost all organic materials that a breeder or a farm would provide them but it is essential that the food being placed in the bin should not exceed the size of half an 
inch or smaller to ensure a quick process of decomposition. Macro and microorganisms in the pile will first break down the chopped and shredded food into smaller pieces by a process called "Initial composting" to prepare it for the worm's consumption since it is in a form that doesn't require teeth or biting (as a worm doesn't have the ability to do that). Some forms of wastes or "feed" can lack softness for the worm to consume but it would degrade eventually by the help of the macro and microorganisms as well as the bacteria present in the pile. There are specific kinds of food that are prohibited upon worms due to their negative effects on them. This might include any material that contains the chemical limonene, which is a chemical compound found mostly in citruses that are considered poisonous for vermi-worms.

Therefore, it is advised to limit citrus food and spicy substances such as hot pepper, even hair, and eggs. Although materials such as dairy, oils, and meat can be allowed, it is advised to prevent them due to the smell they might create in the pile that can affect the worm and the breeder. Food such as vegetable wastes (in certain quantities), grains, manure, fruits, coffee grounds, and agricultural wastes are highly recommended for the feeding of earthworms and for an effective and quick Vermicomposting [7]. Vermi worms have the capability of digesting different kinds of wastes as well such as agricultural wastes [33], municipal solid wastes [34], animal wastes [35], organic solid wastes [36,37] even herbal pharmaceutical wastes [38]. In addition, recent studies have shown that vermicompost can also be used to recycle human excreta [22].

\section{Climate}

The climate varies from a country to another which is why there is a noticeable difference in some of the vermicomposting methods. If the temperature is not monitored inside the pit every week, it can cause an unexpected death of the worms due to the heat generated in hot continents. The worms would work at a 5-10 ${ }^{\circ} \mathrm{C}$ but the process would be slower, thus, even in cold continents, the pile should be measured for maintenance. Eisenia foetida feeds most when the pile is in the suitable temperature of about 15-30 oc [28].

Therefore, in order to receive fast and effective vermicompost, green waste should be added moderately to avoid overheating the bin and outdoors bins should be kept in the shade to avoid direct sunlight

\section{Further Studies on Vermicomposting}

Vermicompost is an excellent soil additive made up of digested compost by earthworms, therefore, is considered as a higher value product [13] and is capable of being exported as a global contestant. A chemical study of worm manure was conducted by Ruz-Jerez et al. [39] and Parkin and Berry [40] respectively that proved worm manure can contain 5 times the available nitrogen, 7 times the available potash (alkaline potassium compound) and 1.5 times more calcium than that found in $15 \mathrm{~cm}$ of good topsoil. In addition, the nutritional life of vermicompost is up to 6 times more in comparison to the other types of organic composts. The phosphorous passes through the worms gut and is transformed into the plant suitable component [41]. Therefore, any process that can increase the availability of phosphorus to the plants is considered essential for the plant's growth and better agriculture.

Vermicompost is rich in microbial organisms and nutrients (that is important for plant growth and productivity) that have long lasting effects, unlike potting soil mixes in the market that are usually sterile. Vermicompost enhances the water retention capacity of the soil by modulating its physical structure. Vermicompost has also been observed to increase the aggregated stability and soil porosity of a plant [42] and increases the number of largely elongated soil macropores, which is the space in the soil that holds water and oxygen. These changes enhance the access of moisture and air which is a major factor in controlling root growth and seedling emergence of a plant [43]. In a study by Kale [44], it was reported that the nutritional status of vermicompost increased an average of $1.5 \%$ to $2.2 \%$ nitrogen $(\mathrm{N}), 1.8 \%$ to $2.2 \%$ phosphorous (P) and $1.0 \%$ to $1.5 \%$ potassium $(\mathrm{K})$ with the use of organic waste. In addition, the vermicompost also contained micronutrients, like Calcium and Magnesium, Copper, Zinc, and Sulphur where they all increased noticeably. In addition, a noticeable decrease in $\mathrm{C} / \mathrm{N}$ (carbon to nitrogen ratio) has been observed when Vermicompost was applied to soil for 60 consecutive days, as well as an increase in heavy metal content of iron, copper, and manganese has [33]. In another study by Nagavallemma et al. [45], it was observed that the worm manure contained a higher percentage (nearly two-fold) of both macro and micronutrients than other garden composts, which proves that Vermicompost enhances the uptake of nutrients by the roots.

Another study was conducted in India by Ansari [46] where he observed the production of potato (Solanum tuberosum) after application of vermicompost in a reclaimed sodic soil (of high sodium content) and concluded that with good potato growth, the sodicity (ESP) of the soil was also reduced from an initial $96.74 \mathrm{~kg} /$ ha to $73.68 \mathrm{~kg} / \mathrm{ha}$ in the 12 weeks of the study. In addition, the average available nitrogen $(\mathrm{N})$ content was also observed to increase in the soil from an initial $336.00 \mathrm{~kg} / \mathrm{ha}$ to $829.33 \mathrm{~kg} / \mathrm{ha}$. This is due to the vermi-worms containing enzymes like amylase, lipase, cellulase, and chitinase in their canal, which can degrade the organic matter in the soil to release the essential nutrients and make it easily obtainable to absorption by the plant's roots [47].

Studies by Edwards and Arancon [48] reported a statistically significant decrease in arthropods (such as mealy bugs and spider mite) infesting the soil and a noticeable reduction in plant damage in tomato, pepper, and cabbage trials with $20 \%$ and $40 \%$ vermicompost additions. In a study by Capowiez et al. [49] the water retention of the soil had increased in an experiment involving earthworms from a mean value of $20 \%$ to $25 \%$ which proofs that vermi-worms increased the availability of water in the soil. A proof that vermicompost is beneficial and saves time and energy is an American study that indicated that 10,000 worms in 
a farm plot provide the same benefit as three farmers working 8 hours in a shift all year round with 10 tons of manure applied in the plot [50].

One of the benefits of Vermicompost that was studied is that humic acid is a stimulant to plant growth (even with minor percents) [51]. The humus contains the humid acid which plays a significant role in the plants in more than one way. It helps the plant extract the nutrients from the soil as well as dissolve the undissolved minerals to make the organic matter ready for the plants' consumption. It stimulates the plant's growth and enables the plant to overcome stress. It has also been proven by $\mathrm{Li}$ and $\mathrm{Li}$, 2010 that the humus in the soil helps chemical fertilizers work better. Moreover, Ayres [52] reported that root diseases in the plant were reduced from 82 to $18 \%$ in tomato when Vermicompost was applied and similarly in capsicum where the percentage dropped from 98 to $26 \%$.

The cast contains a higher bacterial population than the soil or the worm's gut where a study concluded that the microbial activity of beneficial microorganisms in worm castings is high than that of soil or other organic matter by $10-20 \%$ [53]. The bacterial content in Vermicompost ranged from 102-106 per gram of Vermicompost in a study by Suhane [54]. These bacteria included Actinomycetes, Azotobacter, Rhizobium, Nitrobacter, and Phosphate solubilizing Bacteria. Other soil microbes that are stimulated by earthworms include nitrogen-fixing and phosphate solubilizing bacteria and mycorrhizal fungi.

Among other benefits of vermicompost is that the castings can hold more than its weight by 2-3 times in soil and do not burn the root's systems. In addition, it is odorless and $100 \%$ recyclable which is why it is considered a stable alternative. Vermicompost can insulate roots from extreme temperature as well as control weeds and reduce erosion. It is filled with many capabilities such as "high porosity", "aeration", "drainage" and "water holding capacity" than the traditional compost which is due to its humus contents [55].

Various studies stated that Plant Growth Regulating Activity is among the advantages of Vermicompost. It's proven that the growth responses of plants from vermicompost appeared more like "hormone-induced activity" [56,57]. Various studies on different plants have concluded that Vermicompost stimulated seed germination such as of green gram [58], tomato plants, [59], petunia [60] and pine trees [61]. Vermicompost also stimulates vegetative growth, shoot and root development [62]. Application of vermicompost increases fruit yield [63,64] and number of flowers produced $[60,65]$ and changes the seeding morphology of a plant (such as increasing leaf area and root branching) [63].

Vermicompost limited the soil born fungal diseases and surprised the parasitic nematodes in plants when applied by Edwards et al. [61] in field trials with pepper, tomatoes, strawberries, and grapes. This phenomenon explained that the agronomic microbial population in the Vermicompost protects the plants by outcompeting plant pathogens for available food resources and blocking their excess to plant roots by occupying all the available sites.

Vermicompost can be used in sludge transformation into a better product as the results by Jian Yang et al. [66] showed that it lowered the $\mathrm{pH}$ level and water-extractable organic carbon when vermicompost was applied for 3 weeks, along with higher electrical conductivity and nearly two times higher content of water-extractable nitrate (WEN-NO3(-)) than the control. In addition, a Fourier transform infrared spectra (FT-IR) was performed by Jian Yang and revealed that vermicompost promoted the transformation of macromolecular organic matters and accelerated the degradation of polysaccharide-like and proteinlike materials.

Various forms of wastes end up in the environment when it is not disposed of safely. Therefore, vermicompost isn't just an agricultural phenomenal addition, it is a sustainable method for waste control and management such as Solid waste [67] or agricultural waste [30]. Vermicompost can be used in controlling water sludge waste as well. Studies even proved that vermicompost can be used to manage paper waste [68] and even agro-industrial waste management [69-71].

\section{Conclusion}

The rapid increase in population numbers and changes in lifestyle resulted in huge amounts of waste in dumpsters and landfills, causing damage to the environment. Therefore, this review's aim is to act as a comprehensive guide to Vermicomposting as Vermicompost is the best choice among the safe technologies of waste management. It focuses on recycling of different types of wastes and converting them to new products that are environmentally friendly, economic and useful for agriculture.

The earthworms and microorganisms convert organic waste to Vermicompost through a complex environmental and biological practice that stabilizes the organic matter and maintains the complex food webs and the improvement of food elements that are rich in plant nutrients, thus, the Vermi-worm is a small environmental engineer that can solve a lot of disasters that confront our environment and limits the various contaminants to maintain the ecosystems. Vermicompost can be used in all types of farming fields in small and large scales as well as domestic gardens to transform home wastes.

The proper management, minimization and recycling of these wastes in agriculture should be our style of living in order to preserve our resources for future generations, stabilizing and sustaining the health of the environment and society and promote the revolution of discoveries regarding the golden fertilizer in farming via worms and is the best option available in healthy agriculture.

\section{References}

1. Karak T, Bhagat RM, Bhattacharyya P (2012) Municipal solid waste generation, composition, and management: the world scenario. Crit Rev Environ Sci Technol 42(15): 1509-1630. 
2. Leal Filho W, Brandli L, Moora H, Kruopienè J, Stenmarck Å (2016) Benchmarking approaches and methods in the field of urban waste management. Journal of Cleaner Production 112; 4377-4386.

3. Daskalopoulos E, Badr O, Probert SD (1999) Economic and Environmental Evaluations of Waste Treatment and Disposal Technologies for Municipal Solid Waste. Applied Ecology 58(4): 2009-255.

4. Hoornweg D, Thomas L (1999) What a waste: Solid waste management in Asia. Washing-ton, DC, USA: World Bank Urban waste management working paper series no.1.

5. Sudhangshu Kumar Biswas, Rahman S, Kobir SMA, Ferdous T, Banu NA (2014) A Review on Impact of Agrochemicals on Human Health and Environment: Bangladesh Perspective. Plant Environment Development 3(2): 31-35

6. Guerrero RD (2009) Commercial vermimeal production: Is it feasible? In: Guerrero RD (Eds.), Vermi Technologies for Developing Countries. Proceedings of the International Symposium-Workshop on Vermi Technologies for Developing Countrie, Los Baños, 16-18 November 2005, 112-120.

7. Sam Angima, Michael Noack, Sally Noack (2011) Composting with Worms.

8. Goldstein LN (1995) Cleaning up contaminated soils. Biocycle 67: 134139.

9. Adhikary S (2012) Vermicompost, the story of organic gold: A review. Agricultural Sciences 3(7): 905-917.

10. Tweib SA, Rahman RA, Kalil MS (2011) A Literature Review on the Composting. International Conference on Environment and Industrial Innovation 12: 124-127.

11. Naikwade PV, Mogle U, Jadhav B (2011) Comparative study of aerobic and anaerobic com-posts prepared from autumn leaves on Zea mays $\mathrm{L}$. Science Research Reporter 1(2):77-82.

12. Waksman SA (1925) What Is Humus? Proceedings of the National Academy of Sciences of the United States of America 11(8): 463-468

13. Uma Maheswari N, Priya M (2018) Vermicompost a backbone for sustainable agriculture - review article. EJBPS 5(1): 835-846.

14. Vermi Co (2001) Vermicomposting technology for waste management and agriculture: An executive summary. Vermi Co., Grants Pass.

15. Tara Crescent (2003) Vermicomposting. Development Alternatives (DA) sustainable liveli-hoods.

16. Julka JM (1983) A new genus and species of earthworm (Octochaetidae: Oligochaeta) from South India. Geobioscience New Reports 2: 4850.

17. Satyawati Sharma, Kaviraj Pradhan, Santosh Satya, Padma Vasudevan (2005) Potentiality of Earthworms for Waste Management and in Other Uses - A Review. The Journal of American Science 1(1): 4-16.

18. Geetha Karuppasamy, Michael Antony D'Couto, Sangeetha Baskaran, Anant Achary (2017) Biotransformation of Various Wastes into a Nutrient Rich Organic Biofertilizer - a Sustainable Approach towards Cleaner Environment. Biotech Sustainability pp. 212-222.

19. Hao X, Hu H, Li X, Jiang D, Zhu L, et al. (2016) Adaptability comparison of E. fetida in vermicomposting against sludge from livestock wastewater treatment plant based on their several growth stages. Environ Sci Pollut Res 23(15): 15452-15459.

20. Manyuchi MM, Mbohwa C, Muzenda E (2018) Biological treatment of distillery wastewater by application of the vermifiltration technology. South African Journal of Chemical Engineering 25: 74-78.

21. Tiziana Centofanti, Rufus L Chaney, Nelson Beyer W, Laura L McConnell, Allen P Davis, et al. (2016) Assessment of Trace Element Accumu- lation by Earthworms in an Orchard Soil Remediation Study Using Soil Amendments. Water Air Soil Pollution 227(9): 1-14.

22. Vishwa Chandra. Training materials on composting and Vermicomposting. Innovative Ecological Sanitation Network India (IESNI). p. 40.

23. Hung-Wen Liu, Lew Mander (2010) Comprehensive Natural Products II, Chemistry and Biology. Chapter 4.09 - Chemical Defense and Toxins of Lower Terrestrial and Freshwater Animals. Elsevier Volume 4: 387 410.

24. Glenn Munroe (2007) Manual of On-Farm Vermicomposting and Vermiculture. Organic Agriculture Centre of Canada. p. 1-40.

25. Shilpa Shrimal, Meena Khwairakpam (2010) Effect of C/N ratio on Vermicomposting of Vegetable Waste. Dynamic Soil Dynamic Plant 4(1): 123-126.

26. Senthilkumar Palaniappan, Murugappan Alagappan, Rajkumar Ramesh (2017) Influence of Aeration on Vermicomposting of Pre-Processed Vegetable Waste. Indian Journal of Science and Technology 10(12): $1-14$

27. Hernández DJS, Hernández MF, Esparza-Rivera Juan, Ortiz JCR, De La Cruz Lazaro, et al. (2016) Use of vermicompost in the production of melon fruits and their nutraceutical quality. Interciencia 41: 213-217.

28. Yvonne Indrani Ramnarain, Abdullah Adil Ansari, Lydia Ori (2019) Vermicomposting of different organic materials using the epigeic earthworm Eisenia foetida. International Journal of Recycling of Organic Waste in Agriculture 8(1): 23-36.

29. Ismail SA (2005) The earthworm book. Other India Press, Mapusa, pp. 101.

30. Mercy Manyuchi, Anthony Phiri (2013) Vermicomposting in Solid Waste Management: A Review. International Journal of Scientific Engineering and Technology 2(12): 1234-1242.

31. Karmakar S, Brahmachari K, Gangopadhyay A, Choudhury SR (2012) Recycling of Different Available Organic Wastes through Ver-micomposting. E-Journal of Chemistry 9(2): 801-806.

32. April Vigardt (2012) Vermicomposting Systems Southern Illinois University. 1-50.

33. Shak KP, Wu TY, Lim SL, Lee CA (2014) Sustainable reuse of rice residues as feedstocks in vermicomposting for organic fertilizer production. Environ Sci Pollut Res Int 21(2): 1349-1359.

34. Kaviraj, Satyawati Sharma (2003) Municipal solid waste management through vermicompost-ing employing exotic and local species of earthworms. Bioresource Technology 90(2): 169-173.

35. Rhonda Sherman (2013) Vermicomposting Animal Manure. Animal Manure Management.

36. Lim SL, Lee LH, Wu TY (2016) Sustainability of using composting and vermicomposting technologies for organic solid waste biotransformation: recent overview, greenhouse gases emissions and economic analysis. J Clean Prod 111: 262-278.

37.Zerihun Getachew, Tigist Adisu, Lejalem Abeble, Bekele Anbessa (2018) Vermicompost Potential of Common Earthworms (Eudrilus eugeniae) and Red Wiggler (Eisenia fetida) Worm on the Decomposition of Various Organic Wastes. International Journal of Plant \& Soil Science 24(3): $1-13$

38. Singh D, Suthar S (2012) Vermicomposting of herbal pharmaceutical industry waste: earthworm growth, plant-available nutrient and microbial quality of end materials. Bioresour Technol 112: 179-185.

39. Ruz-Jerez BE, Ball PR, Tillman RW (1992) Laboratory assessment of nutrient release from a pasture soil receiving grass or clover residues, in the presence or absence of Lumbricus rubellus or Eisenia fetida. Soil Biology and Biochemistry 24(12): 1529-1534. 
40. Parkin TB, Berry EC (1994) Nitrogen transformations associated with earth worm casts. Soil Biology and Biochemistry 26(9): 1233-1238.

41. Reinecke AJ, Viljoen SV, Saayman R (1992) The suitability of Eudrilus eugenie, Perionyx excavatus and Eisenia fetida (Oligochaeta) for vermicomposting in southern Africa in terms of their temperature requirements. Soil Biology and Biochemistry 24(12): 1295-1307.

42. Ferreras L, Gomez E, Toresani S, Firpo I, Rotondo R (2006) Effect of organic amendments on some physical, chemical and biological properties in a horticultural soil. Biore-source Technology 97(4): 635-640.

43. Gopinath KA, Supradip S, Mina BL, Pande H, Kundu S, et al. (2008) Influence of organic amendments on growth, yield and quality of wheat and on soil properties during transition to organic production. Nutrient Cycling in Agroecosystems 82(1): 51-60.

44. Kale RD (1995) Vermicomposting has a bright scope. Indian Silk 34: 6-9.

45. Nagavallemma KP, Wani SP, Stephane L, Padmaja VV, Vineela C, et al (2004) Vermicomposting: Recycling wastes into valuable organic fertilizer. Global Theme on Agrecosystems Re- port No. 8. Patancheru 502 324, International Crops Research Institute for the Semi-Arid Tropics, Andhra Pradesh, p. 20.

46. Ansari AA (2008) Effect of Vermicompost on the Productivity of Potato (Solanum tuberosum) Spinach (Spinacia oleracea) and Turnip (Brassica campestris). World Journal of Agricultural Sciences 4(3): 333-336.

47. Pathma J, Sakthivel N (2012) Microbial diversity of vermicompost bacteria that exhibit useful agricultural traits and waste management potential. SpringerPlus 1: 26.

48. Arancon NQ Edwards CA, Atiyeh R (2004) Effects of vermicomposts produced from food waste on the growth and yields of greenhouse peppers. Bioresour Technol 93(2): 139-144.

49. Capowiez Y, Cadoux S, Bouchand P, Roger-Estrade J, Richard G, et al (2009) Experimental evidence for the role of earthworms in compacted soil regeneration based on field observations and results from a semi-field experiment. Soil Biology and Biochemistry 41(4): 711-717.

50. Li KM (2005) Vermiculture industry in circular econ- omy. Biotechnology 10: 1-6.

51. Canellas LP, Olivares FL, Okorokova AL, Facanha RA (2002) Humic acids isolated from earth- worm compost enhance root elongation, lateral root emergence, and plasma membrane $\mathrm{H}+$-ATPase activity in maize roots. Plant Physiol 130(4): 1951-1957.

52. Ayres M (2007) Suppression of soil born plant disease using compost. $3^{\text {rd }}$ National Compost Research and Development Forum Organized by COMPOST Australia, Murdoch University, Perth.

53. Edwards CA (1995) Historical overview of vermicomposting. Biocycle 36: $56-58$

54. Suhane RK (2007) Vermicompost. Rajendra Agriculture University, Pusa, p. 88.

55. Atiyeh RM, Subler S, Edwards CA, Bachman G, Metzger JD, et al. (2000) Effects of Vermicomposts and Composts on Plant Growth in Horticultural Container Media and Soil. Pedobiologia 44(5): 579-590.

56. Edwards CA, Burrows I (1988) The potential of earthworms composts as plant growth media. In: Edward CA, Neuhauser EF (Eds.), Earthworms in Waste and Environmental Management. SPB Academic Publishing, The Hague, p. 21-32.
57. Karmegam N, Alagumalai K, Daniel T (1999) Effect of vermicompost on the growth and yield of green gram (Phaseolus aureus Roxb.). Tropical Agriculture 76(2): 143-146.

58. Zaller JG (2007) Vermicompost as a substitute for peat in potting media: Effects on germina-tion, biomass allocation, yields and fruit quality of three tomato varieties. Scientia Horticulturae 112(2): 191-199.

59. Arancon NQ Edwards CA, Babenko A, Cannon J, Galvis P, et al. (2008) Influences of vermicomposts, produced by earthworms and microorganisms from cattle manure, food waste and paper waste, on the germination, growth and flowering of petunias in the greenhouse. Applied Soil Ecology 39(1): 91-99.

60. Lazcano C, Sampedro L, Zas R, Domínguez J (2010a) Vermicompost enhances germination of the maritime pine (Pinus pinaster Ait.). New Forest 39(3): 387-400.

61. Edwards CA, Arancon N (2004) Vermicompost suppresses plant pests and disease attacks. Rednova News.

62. Arancon NQ, Edwards CA, Bierman P (2004) Influences of vermicomposts on field strawberries: Effects on growth and yields. Bioresour Technol 93(2): 145-153.

63. Singh R, Sharma RR, Kumar S, Gupta RK, Patil RT (2008) Vermicompost substitution influences growth, physiological disorders, fruit yield and quality of strawberry (Fragaria xananassa Duch). Bioresource Technology 99(17): 8507-8511.

64. Atiyeh RM, Arancon N, Edwards CA, Metzger JD (2002) The influence of earth-worm-processed pig manure on the growth and productivity of marigolds. Bioresour Technol 81(2): 103-108.

65. Lazcano C, Arnold J, Tato A, Zaller JG, Domínguez J (2009) Compost and vermicompost as nursery pot components: Effects on tomato plant growth and morphology. Spanish Journal of Agricultural Research 7(4): 944-951.

66. Jian Yang, Baoyi Lv, Jie Zhang, Xing Meiyan, (2013) Insight into the roles of earthworm in vermicomposting of sewage sludge by determining the water-extracts through chemical and spectroscopic methods. Bioresource Technology 154: 94-100.

67. Asha Aalok, Tripathi AK, Soni P (2008) Vermicomposting: A Better Option for Organic Solid Waste Management. J Hum Ecol 24(1): 59-64.

68. Muddasir Basheer, Agrawal OP (2013) Management of paper waste by vermicomposting using epigeic earthworm, Eudrilus eugeniae in Gwalior, India. Int J Curr Microbiol App Sci 2(4): 42-47.

69. Nuntawut Champarngam, Chuleemas B Iwai, Mongkon Ta-Oun (2010) Vermicompost: Tool for agro-industrial waste management and sustainable agriculture. International Journal of Environmental and Rural Development 1-2: 38-43.

70. Edwards CA, Domínguez J, Arancon NQ (2004) The influence of vermicomposts on plant growth and pest incidence. In: Shakir SH, Mikhail WZA (Eds.), Soil Zoology for Sustainable Development in the $21^{\text {st }}$ Century. Cairo, pp. 397-420.

71. Li K, Li PZ, Li H (2010) Earthworms helping economy, improving ecology and protecting health. In: Sinha RK, et al. (Eds.), Special Issue on "Vermiculture Technology". International Journal of Environmental Engineering $10(3-4)$. 
This work is licensed under Creative Commons Attribution 4.0 License DOI: 10.19080/ARTOAJ.2019.21.556153

\section{Your next submission with Juniper Publishers} will reach you the below assets

- Quality Editorial service

- Swift Peer Review

- Reprints availability

- E-prints Service

- Manuscript Podcast for convenient understanding

- Global attainment for your research

- Manuscript accessibility in different formats ( Pdf, E-pub, Full Text, Audio)

- Unceasing customer service

Track the below URL for one-step submission https://juniperpublishers.com/online-submission.php 